\title{
GLOBALIZATION AND POLITICAL GEOGRAPHY
}

\author{
FEDERICO ETRO
}

CESIFO WORKING PAPER NO. 986

CATEGORY 1: PUBLIC FINANCE

JULY 2003

Presented at CESifo Area Conference on Public Sector Economics, May 2003

\footnotetext{
An electronic version of the paper may be downloaded

- from the SSRN website: www.SSRN.com

- from the CESifo website: www.CESifo.de
} 


\title{
GLOBALIZATION AND POLITICAL GEOGRAPHY
}

\begin{abstract}
I study a model of geopolitical organization endogenizing the size of nations, of their public spending and of their degree of openness. The optimal geography may not be a stable equilibrium and the Alesina-Spolaore bias toward too many nations tends to be confirmed. However, multiple equilibria can emerge with globalization backlash associated with large nations and high protectionism and equilibria with smaller countries and high openness which are also Pareto superior. A dynamic version of the model shows stable paths of decreasing size of nations, increasing globalization and (at least initially) increasing public spending. Such a process seems consistent with the historical experience, but it may converge toward a steady state with excessive globalization, too many countries and typically too much government spending.
\end{abstract}

JEL Code: H1, H4, E6, F0.

\author{
Federico Etro \\ Ministry of Economy \\ Via XX Settembre 97 \\ 00187 Rome \\ Italy \\ federico.etro@tesoro.it
}

I am thankful to Alberto Alesina, Massimo Bordignon, Roger Gordon, Mark Gradstein, Thierry Mayer, Assaf Razin, Michaele Smart, HansWerner Sinn, Enrico Spolaore, Oved Yosha and other seminar participants at the CESifo Conference on Public Sector Economics in Munich and the CEPR Conference on Macroeconomics and Economic Geography in Modena for useful comments. The paper was written at the National Bureau of Economic Research, which was a very stimulating research environment. The opinion expressed in the paper are not necessarily shared by the Ministry of Economy of Italy. 


\section{Introduction}

Three fundamental political and economic phenomena of the last century have been the raise of public spending, the break up of nations in smaller states or more decentralized countries and the increased integration of international markets. While the first phenomenum has probably achieved its peak and may now reverse, the processes of decentralization and globalization are still in their full momentum. This paper tries to provide a partial but consistent explanation for these phenomena, for their simultaneity and, possibly, for their future evolution.

My starting point is a model by Alesina and Spolaore (1997, AS hence on) who have pioneered the study of the endogenous creation of borders between nations. They emphasize a trade-off between heterogeneity in preferences and scale economies in public good provision as determinant of the size of nations, deriving the optimal size of nations. Despite this optimal solution can be a stable equilibrium, AS emphasize a tendency toward political equilibria with too many small nations.

While AS keep public spending per nation as an exogenous variable, this paper starts by endogenizing the size of public spending of a nation and deriving the optimal size of nations and of their public spending abstracting from issues of globalization. I find that the optimal geography may not be a stable equilibrium because it may imply too large countries from which citizens at the borders would prefer to escape. More exactly, a stable equilibrium geography implies sub-optimal size of nations and governments when public and private consumption are close substitutes, while it may imply over-optimal size of nations and governments when they are imperfect substitutes. This suggests that the historical process of the XXth century toward smaller size nations may be a consequence of the increased sustituibility between private and public goods, where publicly provided private goods are closer substitutes with private goods while pure public goods are less substitutable with private goods.

The next step is to bring into the picture the other crucial factor in the secular decline of the size of nations, the increase in openness (Alesina, Spolaore and Wacziarg, 2000). I introduce globalization, endogenize it and derive the dynamic paths leading toward a steady state political equilibrium for the size of nations and governments and the degree of globalization. The results are quite surprising.

First I show that an increase in the degree of openness tends to reduce the size of countries but also to increase the size of their public sector. Such a result is consistent with the empirical evidence of Rodrik (1998), who finds a clear correlation between openness and size of the public sector. Rodrik offers an explanation based on the greater need of open countries for a stabilizing role of the public sector. My explanation however, supports the empirical results of Alesina and Wacziarg (1998) who show that the crucial channel which drives the above correlation is the fact that more open countries are smaller and more 
homogeneous countries and hence they are more likely to agree on higher public good provision.

Second I show the possibility of multiple equilibria: there can be equilibria with globalization backlash associated with large nations and high protectionism and equilibria with smaller countries and high openness which are also Pareto superior.

Finally, I find that there are stable paths of decreasing size of nations, increasing globalization and (at least initially) increasing public spending which lead toward a steady state. If private and public spending are close substitutes, the steady state is characterized by excessive globalization and too many countries while public spending is typically too much.

The paper is organized as follows. Section 2 introduces the model abstracting from the degree of globalization, derives the optimal organization of the world in terms of number of nations and size of their governments and studies equilibrium outcomes. It also contains a digression which applies our result to an alternative interpretation of our model, that is the federal organization of a country in districts (or regions, or states), and a discussion on the relationship between the process of creation of nations and the one of creation of unions of nations for policy coordination. Section 3 introduces globalization and studies a simple dynamic version of the model to suggest an historical interpretation of the evolution of size of nations, size of governments and globalization. Section 4 concludes.

\section{The Model}

The analysis is based on a spatial model a' la Hotelling (1929). The map of the world is unidimensional and composed by a continuum of agents distributed on the uniform interval $[0,1]$. In the world there are many countries each one with a capital set in the middle of the country (since this is both optimal and an equilibrium outcome). In the capital it is provided a public good whose size is endogenous. ${ }^{1}$

Each citizen chooses how much to work, pays taxes in its own country and enjoys the benefits from public spending according to his or her distance from the public good. Utility for agent $i$ in country $j$ has the following functional form:

$$
U_{i j}=u\left[h_{i j}\left(1-t_{j}\right)\right]-v\left(h_{i j}\right)+H\left(g_{j}\right)\left(\lambda-a l_{i j}\right)
$$

where $u(\cdot)$ is utility from consumption which is income net of taxation at the rate $t_{j}$, and I assume unitary wage, while $v(\cdot)$ is the utility cost of working $h_{i j}$ hours. Finally $H(\cdot)$ is the utility from public spending $g_{j}$ in country $j$ (I

\footnotetext{
${ }^{1}$ For related models on break-up of countries see also Buchanan and Faith (1987), Bolton and Roland (1997), Bordignon and Brusco (2001), Haimanko et al. (2001) and Gradstein (2002b)
} 
will use the less proper expression "public good" interchangeably). Many of the following results will hold with this general model, but to obtain closed form solutions, I will focus on linear utility from consumption, quadratic cost of work and isoelastic utility from public spending, obtaining: ${ }^{2}$

$$
U_{i j}=\frac{g_{j}^{1-\theta}}{1-\theta}\left(\lambda-a l_{i j}\right)+y_{j}-\frac{t_{j}^{2}}{2}
$$

where the parameter $\theta \in[0,1)$ governs the curvature of the utility from public expenditure and represents the elasticity of marginal utility of public expenditure (the lower it is, the more substitute are public and private consumption), $l_{i j}$ is distance from the public good and $t_{j}$ are taxes which imply a quadratic distortion. The parameter $a$ reflects the costs of heterogeneity: in particular we assume that the costs of heterogeneity are linear in the distance from the public good. Finally the parameter $\lambda>0$ parametrizes the absolute utility provided by the public good (for a citizen at distance zero from it). ${ }^{3}$ The tax independnt output $y_{j}=y$ is assumed constant across countries in this section. Let us define the size of country $j$ as $s_{j}$ and the per capita provision of public goods as given by the revenue constraint:

$$
t_{j}=\frac{g_{j}}{s_{j}}
$$

Our focus will be on these two variables.

Our interpretation of the utility function deserves some more comments. I think of the sustituibility between private and public goods (summarized by the parameter $\theta$ ) in a very simple and, hopefully, intuitive way. If publicly provided goods belong to a wide range which starts with purely private goods (drugs or school's books) and arrives to purely public goods (defense), the former typology corresponds to goods with perfect sustituibility with the private goods and the latter one with those that are less substitutable for the private goods.

Also the assumptions on the costs of heterogeneity which are linear in the distance from the public good require a remark. First of all the same distance must be interpreted latu sensu and not literally, however it is typically recognized that regions far away from the capital of a country are the most likely to have at least different preferences from the regions close to the capital, and at most a separatist tendency (the experience of many current and older European

${ }^{2}$ In particular I assume:

$$
U_{i j}=y_{j}+h_{i j}\left(1-t_{j}\right)-\frac{1-\left(1-h_{i j}\right)^{2}}{2}+\frac{g_{j}^{1-\theta}}{1-\theta}\left(\lambda-a l_{i j}\right)
$$

which implies the choice of working hours $h_{i j}=t_{j}$ and hence the indirect utility in the text.

${ }^{3}$ Notice that the model by Alesina and Spolaore (2003) is also different because their costs of heterogeneity are separate from the absolute utility derived from public spending. That assumption would avoid any heterogenity in preferences for public spending, which is clearly an essential element in our model. 
countries is quite clear in this direction). Such a correlation between geographical distance and preference distance is all what we need. Having said this, one may think that the costs of distance from the location of public expenditure are not necessarily linear in this distance. It is probably reasonable to suppose that they are convex in it and I will discuss what such a change implies in Appendix II.

\subsection{Optimal Political Geography}

Let us now examine the social planner solution, that is the optimal organization of the world. It is easy to prove that, because of the uniform distribution of citizens, a social planner would choose countries of equal size $s$ and it would set the public good at the centre of each country. Moreover, it would choose the size of nations and the provision of national public goods so as to maximize:

$$
W=\int_{0}^{1}\left[\frac{g_{j}^{1-\theta}}{1-\theta}\left[\lambda-a l_{i j}\right]+y-\frac{t_{j}^{2}}{2}\right] d i \quad \text { s.v.: } s t_{j}=g_{j}
$$

or, after simple manipulation, it would solve the problem:

$$
\max _{g \geq 0, s \in[0,1]} W=\frac{g^{1-\theta}}{1-\theta}\left(\lambda-\frac{a}{4} s\right)-\frac{1}{2}\left(\frac{g}{s}\right)^{2}+y
$$

If we apply the Alesina-Spolaore rule for the optimal size of nations as a function of public good provision, that is we maximize welfare with respect to $s$ we obtain the first order condition:

$$
W_{s}=-a \frac{g^{1-\theta}}{4(1-\theta)}+\frac{g^{2}}{s^{3}}=0 \quad \Longleftrightarrow \quad s=g^{\frac{1+\theta}{3}} \sqrt[3]{\frac{4(1-\theta)}{a}}
$$

The higher is the provision of the public good, the greater should be the optimal size of nations so as to exploit properly the scale economies, while the higher are heterogeneity costs, the smaller the countries should be. The second implication has been tested by Alesina, Baqir and Hoxby (2002): they show that the number of school districts in a county in United States is higher in more heterogeneous counties in terms of income distribution or racial fragmentation. ${ }^{4}$ Finally, the absolute utility from the public good does not affect the optimal size for a given amount of public good. Summarizing, the optimal size of nations is an increasing and concave function of the provision of public goods.

This optimality condition gives us a first relationship between optimal size of countries and the optimal per capita provision of public goods:

$$
t^{*}=s^{* \frac{2-\theta}{1+\theta}}\left(\frac{a}{4(1-\theta)}\right)^{\frac{1}{1+\theta}} \equiv \psi^{*}(s)
$$

\footnotetext{
${ }^{4}$ See also Strumpf and Oberholzer-Gee (2002).
} 
which is instead an increasing and convex function of $s$ as shown in Fig. 1. Notice that this relationship suggests a positive correlation between size of countries and their public spending per capita. Alesina and Wacziarg (1998) have shown a robust empirical negative correlation between these two variables, hence the simple AS model does not provide a consistent view of this phenomenum.

On the other side, a modified Samuelson rule for optimal public good provision (after Samuelson, 1955) gives us a function of the size of a country which must satisfy the first order condition:

$$
W_{g}=g^{-\theta}\left(\lambda-\frac{a}{4} s\right)-\frac{g}{s^{2}}=0 \quad \Longleftrightarrow \quad g=s^{\frac{2}{1+\theta}}\left(\lambda-\frac{a}{4} s\right)^{\frac{1}{1+\theta}}
$$

which shows that the optimal provision of public goods is an inverted $U$ function of the size of a nation. The latter can be rewritten as a second relationship between optimal size of countries and the optimal per capita provision of public goods:

$$
t^{*}=s^{\frac{1-\theta}{1+\theta}}\left(\lambda-\frac{a}{4} s\right)^{\frac{1}{1+\theta}} \equiv \phi^{*}(s)
$$

which is also shown in Fig. 1. As expected, this is decreasing in the costs of heterogeneity $a$ : less public spending and hence less taxation are better if the costs of benefiting from these public spending are higher. More importantly, the optimal per capita provision of public spending is first increasing in the size of countries and then decreasing, with a peak at $\hat{s}=\frac{4 \lambda}{a}\left(\frac{1-\theta}{2-\theta}\right)$. The intuition is simple. There is a trade off between heterogeneity costs and benefits from scale economies, and both increase in the size of a country. The net benefit from public goods provision is maximized at an intermediate size and the higher are the costs of heterogeneity, the smaller are both the size at which maximum spending is achieved and the same maximum spending. Summarizing, the optimal per capita provision of public goods is a non monotonic function of the size of a nation: small and large countries should have lower taxes and countries of intermediate size should have higher taxes.In the real world, the nature of this non-monotonic relationship is also affected by the nature of the public good. If this is a pure public good, scale economies are quite relevant and the negative relationship between taxes and size should be prevalent, but if the good has private features - as in the case of schools and hospitals - scale economies may be less important and the positive relationship should be prevalent. These implications can be empirically tested at the local level. A preliminary investigation using data from Alesina, Baqir and Easterly (1999) on counties in the United States provides evidence of an inverted U-relationship between average spending in local public goods and size of counties. ${ }^{5}$ The full optimal solution is obtained

\footnotetext{
${ }^{5}$ Using data from Alesina, Baqir and Easterly (1999), we obtained the following result (t-statistics in parenthesis):

$t=5.67+0.16 \log (y)+0.40 s-0.0007 s^{2}-1.18 a+0.09 v$

$\begin{array}{lllll}(1.54) \quad(0.41) & (5.0) \quad(-4.09) & (-2.7) & (3.0)\end{array}$
} 
by solving the system of the two equations. To make the problem interesting, from now on we will assume $a \geq 4 \lambda$ which will guarantee the optimality of at least two countries. Notice that the second order conditions are satisfied. ${ }^{6}$

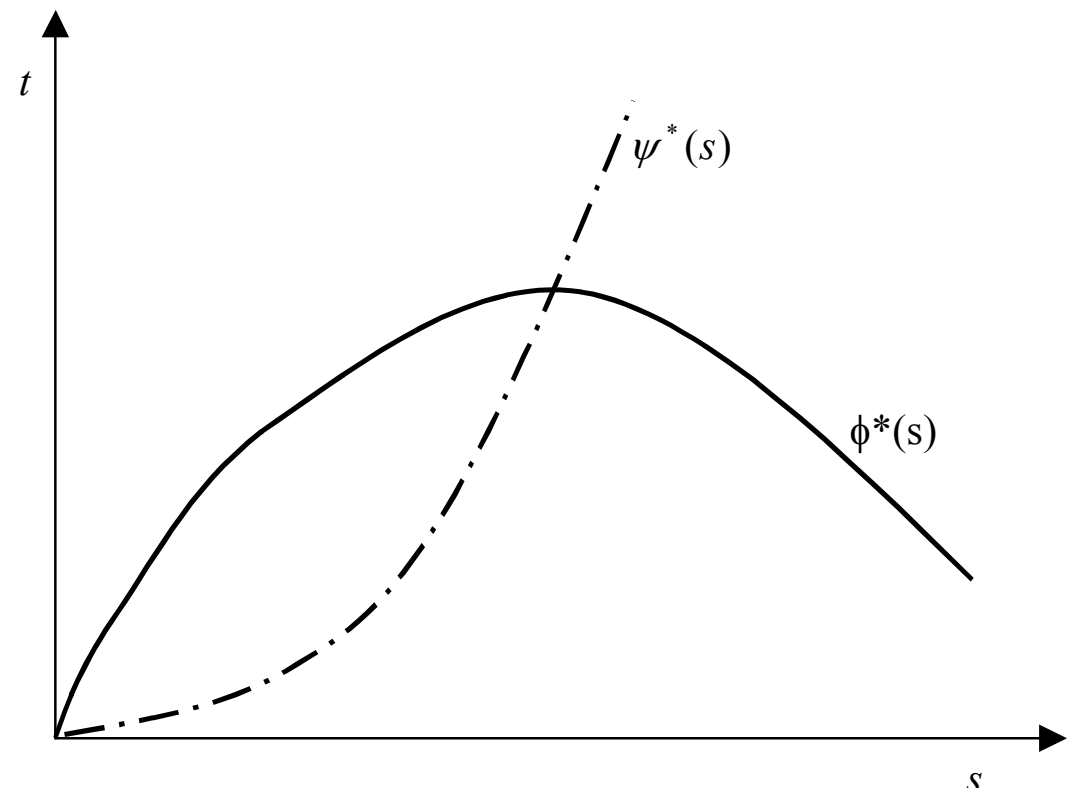

Figure 1. Optimal Geography

Solving the system of optimality conditions we obtain:

$R^{2}=0.183$

where $t$ is the local taxation rate (in percentage points), $y$ is average per capita income, $s$ is population density, $a$ is an index of racial fragmentation, $v$ an index of violence and other control variables are not reported. I have chosen density as a measure for the size of districts because it better describes scale economies than total population. Scale economies not only increase in the number of people benefiting from the public good but also decrease in the necessary fixed costs which are typically related to the dimension of the district (think of roads or multiple schools or hospitals which are necessary when the districts are very wide). Hence density population is the best indicator of the size of districts in the spirit of our model. An inverted U relationship between population density and local tax rates is clear and significant. Notice that district's population enter insignificantly in this regression, once we control for density. Finally it is clear that heterogeneity negatively affects local average expenditure - especially controlling for the index of violence which is correlated to racial fragmentation, but induces more taxes to finance additional police control.

${ }^{6}$ Indeed:

and

$$
\begin{gathered}
W_{s s}=-3 g^{2} / s^{4}<0, \\
W_{g g}=-\theta g^{-\theta-1}(\lambda-a s / 4)-1 / s^{2}<0
\end{gathered}
$$

$$
\Delta \equiv W_{s s} W_{g g}-W_{g s}^{2}=\frac{g^{2}}{s^{6}}(1+\theta)(2-\theta)>0
$$




$$
\begin{gathered}
s^{*}=\frac{4 \lambda}{a}\left(\frac{1-\theta}{2-\theta}\right) \\
t^{*}=\left[\frac{4(1-\theta)}{a}\right]^{\frac{1-\theta}{1+\theta}}\left(\frac{\lambda}{2-\theta}\right)^{\frac{2-\theta}{1+\theta}}
\end{gathered}
$$

In general, the optimal world is composed by $N^{*}=\frac{a}{4 \lambda}\left(\frac{2-\theta}{1-\theta}\right)$ countries, each one with a total provision of the public good:

$$
g^{*}=\left[\frac{4(1-\theta)}{a}\right]^{\frac{2}{1+\theta}}\left(\frac{\lambda}{2-\theta}\right)^{\frac{3}{1+\theta}}
$$

Notice that the optimal number of countries is increasing in the costs of heterogeneity $a$ and decreasing in the absolute utility from the public good $\lambda$, while both total and average expenditure are decreasing in this cost of heterogeneity and increasing in the absolute utility from the public good. This results are in contrast with the basic AS model where an increase in the costs of heterogeneity were reducing the equilibrium size of countries but also increasing the per capita public spending. Finally, the optimal number of nations maximizes per capita provision of public goods, since $s^{*}=\hat{s}$ and it is also increasing in the elasticity of marginal utility of public expenditure $\theta$ : the less substitutable are the public and the private goods (the higher $\theta$ ) the more countries - and so more separate public goods - is optimal to have. Finally, world welfare is: ${ }^{7}$

$$
W^{*}=\left[\frac{4(1-\theta)}{a}\right]^{\frac{2(1-\theta)}{1+\theta}}\left(\frac{\lambda}{2-\theta}\right)^{\frac{2(2-\theta)}{1+\theta}} \frac{1+\theta}{2(1-\theta)}+y
$$

\subsection{Equilibrium Geography}

We now switch to a decentralized world where public spending is chosen by majority voting in each country and agents at a border between a country and another can choose whether to live in one of the two or in autarchy (that is without a public good). In equilibrium we require that no one wants to move from a country to another or to move to autarchy. It is easy to verify that such an equilibrium must be symmetric, that is with countries of equal size. To pin down the set of equilibria we will also require stability. The crucial question will be if the optimal solution derived earlier belongs to the set of stable equilibria.

In a country of size $s$, the favourite public expenditure by citizen $i$ is:

$$
\hat{g}_{i}=\arg \max \left\{\frac{g^{1-\theta}}{1-\theta}\left[\lambda-a l_{i}\right]+y-\frac{(g / s)^{2}}{2}\right\}=\left[\lambda-a l_{i}\right]^{\frac{1}{1+\theta}} s^{\frac{2}{1+\theta}}
$$

\footnotetext{
${ }^{7}$ It is certainly true that to a certain extent also the degree of sustituibility between public and private spending is endogenous. It would be interesting to study such an issue in a more general model.
} 
which is clearly a decreasing function of the distance from the centre. Since single peakedness holds, ${ }^{8}$ the median voter theorem implies the expenditure preferred by the median citizen that is the citizen at distance $l_{m}=s / 4$ from the centre:

$$
\hat{g}_{m}=\left[\lambda s^{2}-\frac{a}{4} s^{3}\right]^{\frac{1}{1+\theta}}
$$

which is the same as the optimal one for any country size since the median citizen is the same as the average in each district. Now, expected utility for a citizen at distance $l$ from the public good in a country of size $s$ is:

$$
\begin{aligned}
V(l) & =\frac{\hat{g}_{m}^{1-\theta}}{1-\theta}[\lambda-a l]+y-\frac{1}{2}\left(\frac{\hat{g}_{m}}{s}\right)^{2}= \\
& =\left(\frac{\lambda-a l}{1-\theta}\right)\left(\lambda s^{2}-\frac{a}{4} s^{3}\right)^{\frac{1-\theta}{1+\theta}}+y-\frac{1}{2 s^{2}}\left(\lambda s^{2}-\frac{a}{4} s^{3}\right)^{\frac{2}{1+\theta}} \\
& =\left(\lambda s^{2}-\frac{a}{4} s^{3}\right)^{\frac{1-\theta}{1+\theta}}\left[\frac{\lambda(1+\theta)-2 a l}{2(1-\theta)}+\frac{a}{8} s\right]+y
\end{aligned}
$$

which is an inverted-U curve in the size of the country $s$. This function of $s$ has a unique peak which is decreasing in $l$. For a citizen at the border of a country of size $s$, that is at distance $s / 2$ from the centre, utility is:

$$
V(s / 2)=\left(\frac{\lambda(1+\theta)-a s(3+\theta) / 4}{2(1-\theta)}\right)\left(\lambda s^{2}-\frac{a}{4} s^{3}\right)^{\frac{1-\theta}{1+\theta}}+y
$$

An equilibrium requires that these agents are at least as well as under anarchy, that is $V(s / 2) \geq y$, which implies $s \leq(4 \lambda / a)(1+\theta) /(3+\theta) .{ }^{9}$ Moreover, in a stable symmetric equilibrium it must be that when two districts of different size share a border, citizens at the border of the bigger country prefer to migrate to the smaller one, so as to re-equilibrate the symmetric outcome. In other words, we require that utility is decreasing in size for the borderline citizens: $V_{s}(s / 2) \leq 0$. Some tedious algebra delivers the final set of stable equilibria:

$$
\begin{aligned}
& s \in\left\{\frac{2 \lambda}{a}\left(\frac{6-3 \theta-\theta^{2}}{6-\theta-\theta^{2}}-\Gamma(\theta)\right), \frac{4 \lambda}{a}\left(\frac{1+\theta}{3+\theta}\right)\right\} \\
& \text { where } \Gamma(\theta) \equiv \frac{\sqrt{12-32 \theta+25 \theta^{2}+2 \theta^{3}-3 \theta^{4}}}{6-\theta-\theta^{2}}
\end{aligned}
$$

\footnotetext{
${ }^{8}$ To verify this notice that the distribution of preferences is uniform and symmetric on the right and on the left of the centre. Hence there are two median citizens with identical preferences, one on the right and one on the left of the centre.

${ }^{9}$ Notice that this constraint is not explicitly taken in consideration by AS where the exogenous amount of public spending requires a fixed and exogenous investment: implicitly they assume that parameters are such that anarchy is never attractive.
} 
In other words, districts cannot be too small or too large in a stable equilibrium. It can be verified that the lower limit to the equilibrium size is decreasing in $\theta$ and always below or equal to the optimal size, while the upper limit is increasing in $\theta$ and below (above) the optimal size if $\theta<(>) 1 / 3$. For instance, if $\theta=0$ we have $s^{*}=2 \lambda / a$ and $s \in\left[s^{*}(1-1 / \sqrt{3}),(2 / 3) s^{*}\right]$ which implies that any stable equilibrium is characterized by suboptimal size of nations (as in AS). This is always true for any $\theta \in[0,1 / 3)$ since in this case the upper bound on the equilibrium size of nations is always below the optimal size. The suboptimal size of nations is associated with suboptimal spending (both in total and average terms). However, for higher enough $\theta$ the optimal geography can be a stable equilibrium. Moreover, for $\theta>1 / 3$ there is the possibility of overoptimal size of nations associated with overoptimal total government spending (the average level is always suboptimal): indeed, when $\theta \rightarrow 1$ we have $s^{*} \rightarrow 0$ but a stable equilibrium belongs to the set $s \in\left[0, \frac{2 \lambda}{a}\right] .{ }^{10}$

Summarizing, the endogenous size of nations and governments is sub-optimal when private and public spending are close substitutes and it may be overoptimal when they are imperfect substitutes. Indeed in the XX century the raise of public spending and the tendency toward an increase in the number of nations started when governments where beginning to publically provide private goods and services as those related to health, education and social security. These public activities are associated with smaller scale economies and higher heterogeneity of views and hence their spreading induced a tendency toward break up of nations in smaller units.

Notice that the result for which the size of nations is sub-optimal when also the size of their per capita public spending is sub-optimal and viceversa is not in contradiction with the empirical result by Rodrik (1998) that larger governments are associated with more open countries, which are also smaller, as emphasized by Alesina and Wacziarg (1998). Indeed, according to this model there is a

\footnotetext{
${ }^{10}$ AS propose a different stability condition which requires that, given two districts with a border in common and sizes $s$ and $s-\varepsilon$, the borderline citizen prefers to be in the smaller size district for any small $\varepsilon>0$. In the simple case with $\theta=0$ this amounts to $V[(s-\varepsilon) / 2] \geq V(s / 2)$ or, after some manipulations:
}

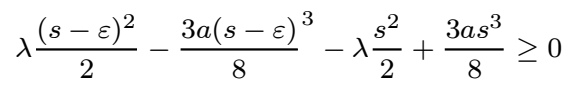

from which:

$$
\begin{gathered}
\lambda\left[s^{2}-(s-\varepsilon)^{2}\right]=\lambda[s-(s-\varepsilon)][s+(s-\varepsilon)] \leq \\
\leq \frac{3 a}{4}\left[s^{3}-(s-\varepsilon)^{3}\right]=\frac{3 a}{4}[s-(s-\varepsilon)]\left[s^{2}+(s-\varepsilon)^{2}+s(s-\varepsilon)\right] \\
\Leftrightarrow \lambda \varepsilon(2 s-\varepsilon) \leq \frac{3 a}{4} \varepsilon\left(3 s^{2}+\varepsilon^{2}-2 s \varepsilon\right)
\end{gathered}
$$

Dividing by $\varepsilon$ and taking the limit for $\varepsilon \rightarrow 0$ one obtains:

$$
s \geq \frac{8 \lambda}{9 a}
$$

which is a stricter condition than the one adopted in the text. 
general tendency toward too many countries with too small governments or too few countries with too big governments, but in equilibrium all countries have the same size. In the real world it may be that, despite the relationship found by Rodrik (1998) and Alesina and Wacziarg (1998) across countries of different sizes, the average sizes of countries and governments are actually too small or too big. When we will introduce openness in the next section we will actually find out that openness induces countries to become smaller but with a larger public sector, exactly as the empirical evidence suggests.

In this perspective, the historical process of the last century toward smaller size nations (witnessed by Alesina and Spolaore, 2003) may be seen as a consequence of the increased sustituibility between private and public goods. One may view publicly provided private goods as close substitutes with private goods while pure public goods are less substitutable with private goods. It is a well known fact that the diffusion of Communism around the world since the first half of the XXth century and the diffusion of the Welfare State in Western countries in the second half of the XXth century have extended government activity toward publicly provided private goods as education, health and social security. Since scale economies are much less powerful and heterogeneity of views is more acute for these kind of activities than for the traditional public goods on which the governments were focused until then, a tendency toward a decreasing size of nations emerged during the last century.

Further limitations on the set of geographical equilibria could be obtained putting more structure on the political way borders are changed. For instance AS assume that a majority of all countries interested by a reshape of the borders has to accept this change foreseeing the new associated political geography after the change. It turns out that the associated equilibrium is unique and maximizes the utility of the border line citizens. In our context this would correspond to the lower bound of the set of stable equilibria: hence the AS conclusion that equilibrium size is smaller than optimal always holds. An alternative reasonable assumption one can make is that the size of a country can be reduced through a secession of borderline citizens only if a majority agrees but that the capital of the country which is breaking up remains where it was. Such a system avoids the shift of capitals in all the countries associated with the AS system and hence it may appear more reasonable (at least in certain historical periods). It implies convergence toward the optimal size of countries for any $\theta>1 / 3$ and the maximum stable and suboptimal size otherwise. ${ }^{11}$ Hence the AS presumption in favour of sub-optimal size of nations is again (weakly) confirmed.

The previous results seem to suggest that the AS result of suboptimal size

\footnotetext{
${ }^{11}$ The proof is simple: consider a citizen at generic distance $l$ from a public good. His or her favourite size is $s(l)$. As noted earlier, this is a decreasing function of the distance from the centre. Hence single-peakedness holds in the referendum on enlargment or break-up and when the median citizen favourite choice is a stable equilibrium (which happens for $\theta \geq 1 / 3$ ), it is the unique equilibrium. Otherwise, the only equilibrium must be the largest size stable equilibrium. Finally, notice that in this model the median citizen is also the average citizen.
} 
of nations is a quite robust result. In reality they point out a possible source of failure of the AS result: whenever citizens closer to the centre have more power than others in determining the policy, excessive spending and size of countries emerge. $^{12}$ One case where this emerges is when central governments are not democratic and extract rents from the taxation of their citizens: Appendix I shows an example and derives different cases where the equilibrium size and taxes can be suboptimal or above the optimal level. A sub-optimal number of countries may emerge even in a democratic context as the one studied here depending on the relationship between preferences and distance from the centre. In this sense the assumption of linear costs of distance is quite crucial. In Appendix II I study a version of the model with convex costs of heterogeneity in the distance from the public good. In such a model the cost of distance for the median citizen is lower than the average cost of distance (while they are equal with linear costs of heterogeneity). Hence the AS result of suboptimal districts may break up because the median citizen of each district votes for a bigger size government than the one desired by the average citizen and opposes to secessions which would limit the scale economies of their countries. Under this circumstances it may be optimal to coordinate the design of borders so as to limit the centralization bias. ${ }^{13}$ The Appendix shows how this can be done by choosing a size of countries above the first best level.

\subsection{A Digression on Fiscal Federalism}

Our model can be reinterpreted as a model of the organization of a country in districts (or regions, or states), that is as a model of fiscal federalism. In this section I briefly comment on our results from this point of view and their relationship with the literature.

The traditional theory of local public goods associated with Tiebout (1956) finds the optimal solution to the provision of local public goods in a market mechanism based on mobility of citizens between districts and local choice on the provision of public goods. Such a decentralized system is able to sort citizens with different preferences and to allocate them in districts in which the right amount of local public goods is provided. As Tiebout writes, "as the consumer may be visualized as walking to a private market place to buy his goods, the prices of which are set, we place him in a position of walking to a community where the prices (taxes) of community services are set. Both trips take the consumer to market. There is no way in which the consumer can avoid revealing his preferences in a spatial economy. Spatial mobility provides the local publicgoods counterpart to the private market's shopping trip". The Tiebout model

\footnotetext{
${ }^{12} \mathrm{~A}$ related centralization bias emerging in international unions of countries is studied by Alesina, Angeloni and Etro (2001a).

${ }^{13}$ One may view a similar task in the geographical organization of modern colonies in states, provinces and counties. Where history matters less, efficiency reasons are more likely to shape the size of countries and districts within countries.
} 
has been formalized and extended to different kinds of heterogeneity, to realistic features of city environments in the spirit of urban economics and to precise voting mechanisms at the district level in the spirit of political economy. ${ }^{14}$

A parallel literature well represented by Oates $(1972,1999)$, Gordon (1983) and Brueckner (2000) has focused on the advantages of fiscal federalism as a system of decentralized decision making on public expenditure financed both through local decentralized taxation and a net of intergovernmental taxes and grants. In his classic book, Oates (1972) states a Decentralization Theorem for which "in the absence of cost-savings from the centralized provision of a good and of interjurisdictional externalities, the level of welfare will always be at least as high (and typically higher) if Pareto-efficient levels of consumption are provided in each jurisdiction than if any single, uniform level of consumption is maintained across all jurisdictions". ${ }^{15}$

If we abstract from spillovers between districts, the Tiebout model and the Oates model together imply a strong presumption in favour of decentralization. ${ }^{16}$ A crucial assumption made by Tiebout in his analysis was that "communities below the optimum size seek to attract new residents to lower average costs. Those above optimum size do just the opposite. Those at the optimum try to keep their populations constant". Since this is just an assumption and we do not see strong reasons why the sizes of districts should necessarily converge to their optimum level, it seems important to investigate this issue. The issue is also more important because districts of inefficient size may also imply inefficient local public spending, undermining the all Tiebout argument. Is the size of districts too big or too small? and is the local provision of public goods efficient? Our model has provided some tentative answers to these questions.

We found that in general the size of districts is not necessarily the optimal one. Moreover, under reasonable conditions, and especially when public spending is close substitute of private spending (which is most likely to be the case at the local level), the size of districts tends to be suboptimal. However, when citizens closer to the centre have more power than others in determining the policy, excessive spending and size of countries emerge. This implies a new presumption in favour of centralization at least in the shaping of districts (see Appendix II on geographical coordination): more precisely, once a central government has decided the federal structure, each district can individually adopt the optimal spending decision. This may partially counterbalance the advantage

\footnotetext{
${ }^{14}$ See Buchanan (1965), Atkinson and Stiglitz (1980), Boadway and Flatters (1982), Fujita (1989), Ellickson (1971), Brueckner (1979) and Epple and Romer (1991).

${ }^{15}$ More recently Bordignon, Manasse and Tabellini (2001), Besley and Coate (2003), Gradstein (2002a), Alesina, Angeloni and Etro (2001b, 2003) and Etro and Giarda (2002), have compared different institutional organizations for a federation in a political economy perspective.

${ }^{16} \mathrm{An}$ important argument in favour of centralization is based on the possibility of tax competition between districts, which may induce suboptimal taxation and hence suboptimal public spending (Wildasin, 1989, Kanbur and Keen, 1993, Brueckner, 2000) or suboptimal redistribution (Sørensen, 2003).
} 
of decentralization suggested by the traditional literature on fiscal federalism.

\subsection{Centrifugal and Centripetal Forces}

Recent history has been characterized, especially in Europe, by the co-existence of centrifugal forces within nations (pressure towards regional autonomy in most Western European countries and the break-up of some Eastern European nations) and centripetal forces at a supranational level (the tendency to delegate policies to supernational entities like the European Union). These two forces may have a natural interconnection: the benefits from participating in international unions may reduce the equilibrium size of nations. Separatism within nations and delegation of policies to supernational entities could well be complementary parts of the same process. Such an hypothesis is suggested by Alesina, Angeloni and Etro (2003). Here I borrow their simple characterization of intercountry spillovers to provide a simple skecth of how this mechanism may work.

Consider the basic model with $\lambda=1$ and $\theta=0$ for simplicity. Imagine, however, that there are spillovers across countries in their public spending. To normalize the externality that public spending in each country exerts on the other countries, assume that utility for of agent $i$ in country $j$ becomes:

$$
U_{i j}=\left[g_{j}+\beta \bar{g}_{-j}\right]\left(1-a l_{i j}\right)+y-\frac{t_{j}^{2}}{2}
$$

where $\bar{g}_{-j}$ is average public spending abroad and $\beta \in[0,1]$ parametrizes the size of spillovers across national public spendings.

It is standard to verify that the optimal geography would imply world coordination to solve the problem:

$$
\max _{g \geq 0, s \in[0,1]} W=[g+\beta g]\left(1-\frac{a}{4} s\right)+y-\frac{1}{2}\left(\frac{g}{s}\right)^{2}
$$

which implies the optimal size of countries:

$$
s^{*}=\frac{2}{a}
$$

which is independent from the size of spillovers, and the optimal average public spending:

$$
t^{*}=\frac{1+\beta}{a}
$$

which is increasing in the size of spillovers. In general, since fiscal policy is a prosper-thy-neighbour policy, when interdependence across countries increases it is optimal leave the size of countries unchanged and to increase public spending in each country. 
In political equilibrium, however, a country of size $s$ will choose public spending without internalizing the spillovers on the rest of the world. As before the median citizen will impose the choice $g=(1-a s / 4) s^{2}$ which will deliver the indirect utility fucntion:

$$
V(l)=\left(s^{2}-\frac{a s^{3}}{4}\right)\left[(1-a l)(1+\beta)-\left(\frac{1-a s / 4}{2}\right)\right]
$$

The favourite size by a citizen at distance $l$ from the centre of its country satisfies $V_{s}(l)=0$, but since $V_{s \beta}(l)<0$ as it can be easily verified, it turns out that the favourite size of countries by each citizen is decreasing in the size of spillovers across national public spending. the obvious consequence is that when interdependence across countries increases the equilibrium size of nations tends to decrease and public spending decreases in each country.

Clearly, any group of country could be better off by joining in a union to coordinate public spending and such a gain is increasing with the size of spillovers $\beta$. While it is beyond the scope of this paper to model the formation of international unions across countries (see Etro, 2002 and Alesina, Angeloni and Etro, 2001a,b, 2003), the bottom line of this simple extension is that when interdependence across countries increases, there is a tendency toward increasing the number of nations and creating supranational unions for policy coordination.

\section{Endogenous Globalization}

I will now investigate the consequences of globalization on the size of nations and governments assuming that some externalities can be obtained from foreign countries if a country is open, but their importance is reduced when a country is already large (as many endogenous growth and trade models suggest). ${ }^{17}$ In particular, output of country $j$ is linear in the size of country $j$ and linearly related to the size of the rest of the world in proportion to its degree of openness $\varphi_{j} \in[0,1]:$

$$
y_{j}=h s_{j}+h \varphi_{j}\left(1-s_{j}\right)-f\left(\varphi_{j}\right)
$$

where $h>0$ parameterizes the size of the scale effects and $f(\varphi)$, with $f(0)=$ $0, f^{\prime}(\varphi)>0, f^{\prime \prime}(\varphi)>0$ represents the costs of openness, which are usually associated with the redistributive and political consequences of globalization. ${ }^{18}$

\footnotetext{
${ }^{17}$ See for instance Rivera-Batiz and Romer (1990), Grossman and Helpman (1991) and especially the discussion in Alesina and Spolaore (2003).

${ }^{18}$ For an historical view on costs and benefits of globalisation see O'Rourke and Williamson (1999). For related empirical evidence see Spolaore and Wacziarg (2002). Many economists probably agree on the fact that the social cost of openness are only temporary and only the positive net gains from trade remain in the long run. We may have introduced this assumption in the dynamic version of the model but our qualitative results would have not changed.
} 
Notice that I am taking a short cut by assuming that what determines the openness of country $j$ is just the degree of protectionism chosen by the same country $j$. Clearly in the real world also the choices of all the other countries affect the effective openness of country $j$. This complication would imply an interdependence between countries leading to well known bias toward excessive protectionism. Such a limitation should be kept in mind in the evaluation of the future results.

For simplicity let us focus on the case in which $\lambda=1$ and $\theta=0$. The utility of agent $i$ in country $j$ becomes:

$$
U_{i j}=g_{j}\left(1-a l_{i j}\right)+h s_{j}+h \varphi_{j}\left(1-s_{j}\right)-f\left(\varphi_{j}\right)-\frac{t_{j}^{2}}{2}
$$

which clearly corresponds to the case of the previous section when $\varphi=1$, that is under complete globalization.

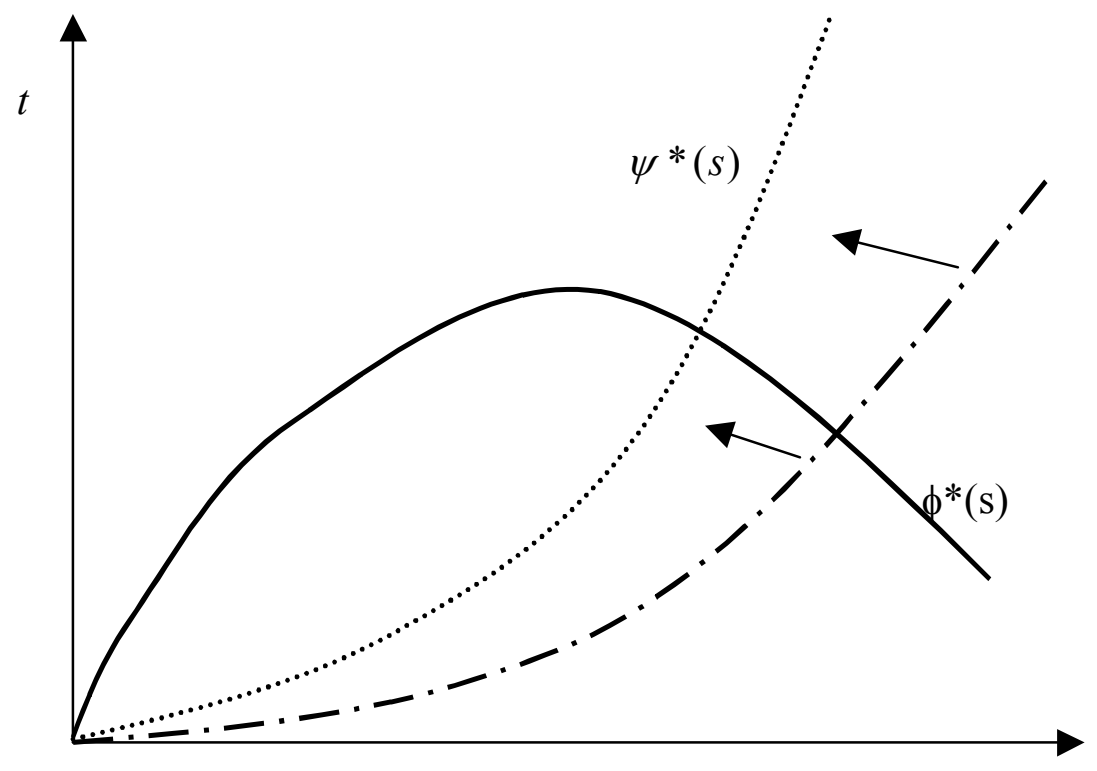

$S$

Figure 2. The Effects of Globalization

First, let us consider the optimal political geography for a given and common degree of openness. World welfare is:

$$
W=g\left(1-\frac{a s}{4}\right)+h[\varphi+s(1-\varphi)]-f(\varphi)-\frac{1}{2}\left(\frac{g}{s}\right)^{2}
$$

The AS rule for the optimal size of countries becomes:

$$
-\frac{a g}{4}+\frac{g^{2}}{s^{3}}+h(1-\varphi)=0
$$


As Alesina, Spolaore and Wacziarg (2000) have emphasized, this implies that the higher is the degree of openness the smaller is the optimal size of countries. Inverting this rule and solving for the per capita public spending we obtain the relevant root:

$$
t^{*}=\frac{s^{* 2}}{2}\left(\frac{a}{4}+\sqrt{\left(\frac{a}{4}\right)^{2}-\frac{4 h(1-\varphi)}{s^{* 3}}}\right) \equiv \psi^{*}(s, \varphi)
$$

which is increasing in the degree of openness: $\psi_{s}^{*}(s, \varphi)>0$ under the regularity condition that $h$ is small enough, as we assume. Notice that $\psi^{*}(0, \varphi)=0$ for any $\varphi$ and $\psi_{s s}^{*}(s, \varphi)>0$ under weak conditions.

The Samuelson rule for the optimal provision of public goods provides:

$$
t^{*}=s\left(1-\frac{a}{4} s\right) \equiv \phi^{*}(s)
$$

which is independent from the degree of openness.

Let us represent globalization as an increase in $\varphi$. Fig. 2 clearly shows that globalization reduces the optimal size of nations $s^{*}(\varphi)$. Moreover one can show that the curve $\psi^{*}(s, \varphi)$ always crosses the curve $\phi^{*}(s)$ after its peak, ${ }^{19}$ hence it follows that globalization induces an increase in the optimal size of public spending. This result has a crucial intuition: when market integration increases for some exogenous reason, it becomes optimal to reduce the size of countries so as to decrease heterogeneity within each country while enjoing spillovers from the rest of the world. Such a process is associated with a greater willingness to increase public spending because more homogeneous countries gain more from their public good provision. Such a conclusion provides an alternative explanation for the empirical finding of Rodrik (1998) who links the correlation between openness and public spending with a greater need for risk sharing and stabilizing activities. Our explanation supports the view of Alesina and Waicziarg (1998) that the crucial channel to explain that correlation is the size of countries: more open countries have larger governments because they are smaller and hence more homogeneous.

\subsection{Optimal Globalization}

Imagine now that the degree of openness is also optimally chosen. Applying the envelope theorem we can focus on the direct effects on output. The optimality condition implies:

$$
h(1-s)=f^{\prime}(\varphi)
$$

Since $d \varphi / d s=-h / f^{\prime \prime}<0$, this shows that smaller economies should be more open, while large economies should be closer, and in general there is a negative

\footnotetext{
${ }^{19}$ This follows since $\psi^{*}(s, 1)>\psi^{*}(s, \varphi)$ for any $\varphi<1$ but $\psi^{*}(s, 1)$ crosses the curve $\phi^{*}(s)$ at its peak.
} 
relationship which goes from size to openness. Inverting this relationship we have:

$$
s=1-\frac{f^{\prime}(\varphi)}{h}=S^{*}(\varphi)
$$

which is another negatively sloped relationship between openness and size. The two optimality relations $s=s^{*}(\varphi)$ and $s=S^{*}(\varphi)$ are shown in Fig. 3 in the space $(\varphi, s)$. It can be shown that in case of more than one crossing, the one with larger globalization is the global optimum.

As an example, let us consider the case in which $f(\varphi)=h \varphi^{2} / 2$ (and we need the regularity condition $h \leq 1 / 8$ to avoid degenerate cases). This implies the optimal degree of openness $\varphi^{*}=1-s^{*}$. The first order condition for the optimal size becomes:

$$
-\frac{a\left[s^{* 2}\left(1-\frac{a}{4} s^{*}\right)\right]}{4}+\frac{\left[s^{* 2}\left(1-\frac{a}{4} s^{*}\right)\right]^{2}}{s^{* 3}}+h s^{*}=0
$$

which is an S-shaped curve in $s^{*}$, which cuts the x-axis first from above and then from below. Since at the optimum the second order condition requires a negative slope of the first derivative, the smaller intersection provides the optimal size:

$$
s^{*}=\frac{3}{a}-\frac{\sqrt{1-8 h}}{a}
$$

the optimal per capita public spending:

$$
t^{*}=\frac{1+4 h+\sqrt{1-8 h}}{2 a}
$$

and the optimal globalization:

$$
\varphi^{*}=1-\frac{3-\sqrt{1-8 h}}{a}
$$

Notice that the optimal size of countries is increasing in $h$ and hence when the scale effects are more important. For the sake of simplicity let us also assume $h=1 / 9$. This delivers the optimal geography:

$$
s^{*}=\frac{8}{3 a} \quad t^{*}=\frac{8}{9 a} \quad \varphi^{*}=1-\frac{8}{3 a}
$$

which implies total spending at the level $g^{*}=64 / 27 a^{2}$.

\subsection{Equilibrium Globalization}

Let us switch to an equilibrium analysis. The natural assumption is that after countries are created with a certain provision of public goods which has 
been voted on, each country votes on the degree of openness. ${ }^{20}$ Under this assumption, a given country of size $s$ and spending $g$ will choose its own level of openness. The utility of the citizen at distance $l$ from the centre is:

$$
V(l)=g[1-a l]-\frac{1}{2}\left(\frac{g}{s}\right)^{2}+h s+h \varphi(1-s)-f(\varphi)
$$

hence every citizen will agree on the optimal degree of openness which satisfies $h(1-s)=f^{\prime}(\varphi)$, exactly as under optimality: this confirms a well known principle of trade theory: small economies prefer to be open, while large economies prefer to be close. The negative relationship between size and openness can be defined as $\varphi=\varphi(s)$ with $\varphi^{\prime}(s)<0$. Hence the indirect utility of the citizen at distance $l$ from the centre becomes:

$$
V(l)=g[1-a l]-\frac{1}{2}\left(\frac{g}{s}\right)^{2}+h s+h \varphi(s)[1-s]-f[\varphi(s)]
$$

Again single-peakedness holds in the choice of public spending and, by the envelope theorem, it is not influenced by the choice on the degree of openness. As previously shown one can derive equilibrium size $s=s^{e}(\varphi)$ and government spending $t=t^{e}(\varphi)$. Now an equilibrium size above the optimal level is certainly associated with a sub-optimal size of governments, while the opposite is generally - but not always - true when equilibrium size is below the optimal level. In the global equilibrium we must have:

$$
\varphi=\varphi\left[s^{e}(\varphi)\right]
$$

The equilibrium relationship $\varphi=\varphi(s)$ can be inverted to obtain $s=S^{*}(\varphi)$. Graphically the two equilibrium relationships $s=S^{*}(\varphi)$ and $s=s^{e}(\varphi)$ can be shown in the space $(\varphi, s)$. They are shown in Fig. 3 for a specific case emphasizing the possibility of multiple equilibria. More importantly these equilibria are Pareto rankable: there can be equilibria with globalization backlash associated with large nations and high protectionism and equilibria with smaller countries and high openness which are also Pareto superior. Notice that the problem of excessive globalization derives from the externalities that the policy of each country has on foreign countries and it could be limited adopting some form of international policy coordination: in this case a commitment to increase (limit) the degree of openness by each country would allow to achieve a Pareto improvement over the equilibrium with globalization backlash (excessive globalization) - see Alesina, Angeloni and Etro, 2003 on the endogenous creation of international unions for policy coordination.

\footnotetext{
${ }^{20}$ The same results would emerge if countries were voting first on the degree of openness and then on the provision of public goods or even conetmporaneously (sequential voting is not strictly necessary to apply the median voter theorem since the prefered degree of openness is the same for all citizens).
} 


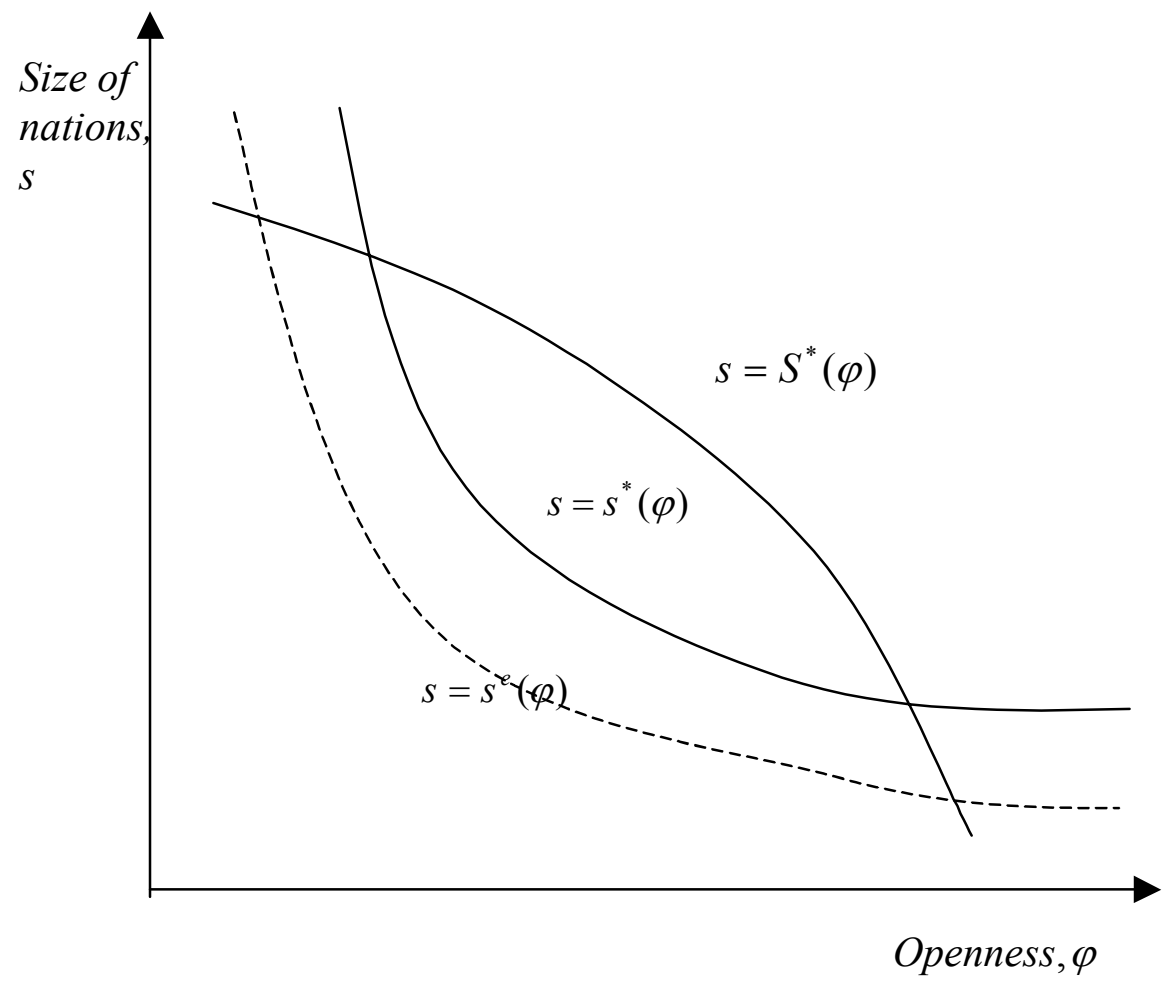

Figure 3. Endogenous Globalization and Multiple Equilibria

If we focus on the best equilibrium, which as we will see in the next section is also the stable one, we can notice that the equilibrium relationship $s^{e}(\varphi)$ is shifted to the left compared to its optimal counterpart $s^{*}(\varphi)$ : this implies that the best equilibrium is associated with excessive globalization and too small countries, while public spending may be too much or too low. ${ }^{21}$ Notice that in

${ }^{21}$ The results would change if we assumed the opposite timing, that is countries initially choosing their level of globalization foreseeing the geographical equilibrium which will follow. Indirect utility of the citizen at distance $l$ from the centre is:

$$
V(l)=g^{e}[1-a l]-\frac{1}{2}\left(\frac{g^{e}}{s^{e}(\varphi)}\right)^{2}+h s^{e}+h \varphi\left[1-s^{e}(\varphi)\right]-f(\varphi)
$$

Again single-peakedness holds and the preferred degree of openness by the median citizen satisfies:

$$
\frac{\partial V(s / 4)}{\partial s} s^{e \prime}(\varphi)+h(1-s)=f^{\prime}(\varphi)
$$

Notice that $s^{e \prime}(\varphi)<0$ and $\frac{\partial V(s / 4)}{\partial s}>0$ since for a given degree of openness, the equilibrium size is suboptimal from the point of view of the average citizen, which is also the median one. Hence, we have an extra cost from an increase in globalization due to the indirect reduction 
the case of complete globalization, the results of the previous section tell us that public spending will be too small, hence one can conjecture that public spending will be typically too much as long as the equilibrium level of globalization is not too high.

Let us turn to the example with $f(\varphi)=h \varphi^{2} / 2$. Given the political equilibrium degree of openness and public spending, the indirect utility of an agent at distance $l$ from the center becomes:

$$
\begin{aligned}
V(l) & =g(1-a l)+h s+h(1-s)^{2}-\frac{h(1-s)^{2}}{2}-\frac{1}{2}\left(\frac{g}{s}\right)^{2}= \\
& =s^{2}\left(1-\frac{a}{4} s\right)(1-a l)+\frac{s^{2}}{2}\left[h-\left(1-\frac{a}{4} s\right)^{2}\right]+\frac{h}{2}
\end{aligned}
$$

Stability of an equilibrium requires $V(s / 2) \geq h / 2$ and $V_{s}(s / 2) \leq 0$. Let us focus on the case in which $h=1 / 9$. Since $V(s / 2)=s^{2}\left(5 / 9-a s / 2-3 a^{2} s^{2} / 32\right)+$ $1 / 18$, the stability condition becomes:

$$
s \in\left[\frac{27-\sqrt{609}}{6 a}, \frac{8(1-1 / \sqrt{6})}{3 a}\right]
$$

which does not include the optimal size of nations. Indeed, under our proposed equilibrium concept, $s^{*}$ is too big and would induce a preference for anarchy of citizens at the borders, and any equilibrium would imply suboptimal size associated with too much public spending per capita if the equilibrium size is not too small.

Despite the results of this example are not general, it emerges that typically political equilibria tend to imply excessive globalization, too many countries and too much government spending per capita.

\subsection{Geopolitical Dynamics}

Our final enquiry is about the dynamic process bringing toward globalization. Fig. 4 shows the dynamics of globalization and size of countries adopting a standard adjustment mechanism for the size of nations and the degree of openness. In particular we assume the following dynamic system:

$$
\begin{aligned}
\dot{s} & =\beta\left[s^{e}(\varphi)-s\right] \\
\dot{\varphi} & =\gamma\left[S^{e}(\varphi)-s\right]
\end{aligned}
$$

where $\beta>0$ and $\gamma>0$ are standard velocity of convergence parameters: When the size of countries is below its equilibrium level for the current degree of

of the equilibrium size of the country. Anyway, multiple equilibria are again possible but we cannot derive general welfare conclusions in this case since both the equilibrium relationships are shifted to the left compared to their optimal counterparts (the only scenario we can exclude is an equilibrium with too few countries and too much globalization). 
openness the size increases. When the degree of openness is below the optimal level for a given size, that is the size of countries is below the level which is consistent with the optimal degree of openness, the latter increases.

For expository purposes Fig. 4 focuses on a case with two steady state equilibria. It emerges that in this case only one of the two equilibria is globally stable, while the other can only be achieved along a saddle path. Focusing on the first one, starting from a condition of globalization backlash and large countries, there are many paths of increasing number of countries and increasing openness of countries which bring to the best steady state equilibrium. Clearly, if there were more than two steady states, there may be poverty traps with stable sub-optimal equilibria.

Such a diagram allows us to attempt a stilyzed reconstruction of world history based on the trade-offs emphasized in this paper. Imagine that the degree of globalization is actually composed by an exogenous part, which largely depends on technological progress and follows a stochastic trend. Its main component is transportation costs, which have been declining over time with structural breaks due to the introduction of new transportation methods, more powerful engines and so on. Despite part of this technological progress may be endogenous, we will neglect such a component. On the other side there is what we may call the endogenous part of the degree of openness which depends on tariff barriers, quotas and other protectionist policies which are politically chosen.

As long as transportation costs were high enough, the degree of openness was very low and the only possible equilibrium was one converging toward $s=1$. In ancient time many Empires were universalistic in nature and tended to extend their power over all the world which was known at the time: the Persian Empire, Greece under Alexander Magnus or the Roman Empire were examples of such a tendency. These periods were also characterized by a very limited role for public spending.

It was only in the Low Medieval age that trasportation costs started to sensibly decline and a revival of trade took place in the Mediterranean sea. That was an age of free trade and it was characterized by a rapid reduction in the size of countries whose peak was achieved when city-states like Venice, Genoa, Lisbon, Antwerp and Amsterdam were dominating trade all over the world.

During the XVII and XVIII centuries the equilibrium size of countries enlarges and big kingdoms like France, Spain, England and Russia emerge. Meanwhile the size of their public spending, which is still focused on pure public goods as defense, increases in absolute levels but remains quite low in per capita terms. It is actually the necessity of a more efficient and wider provision of the latter to be one of the main causes of the evolution toward larger countries in Europe (see Alesina and Spolaore, 2003). This period is also characterized by a smaller degree of openness and the diffusion of merchantilistic theories, and also this fact supports the comparative advantage of larger size countries in ruling the 
world.

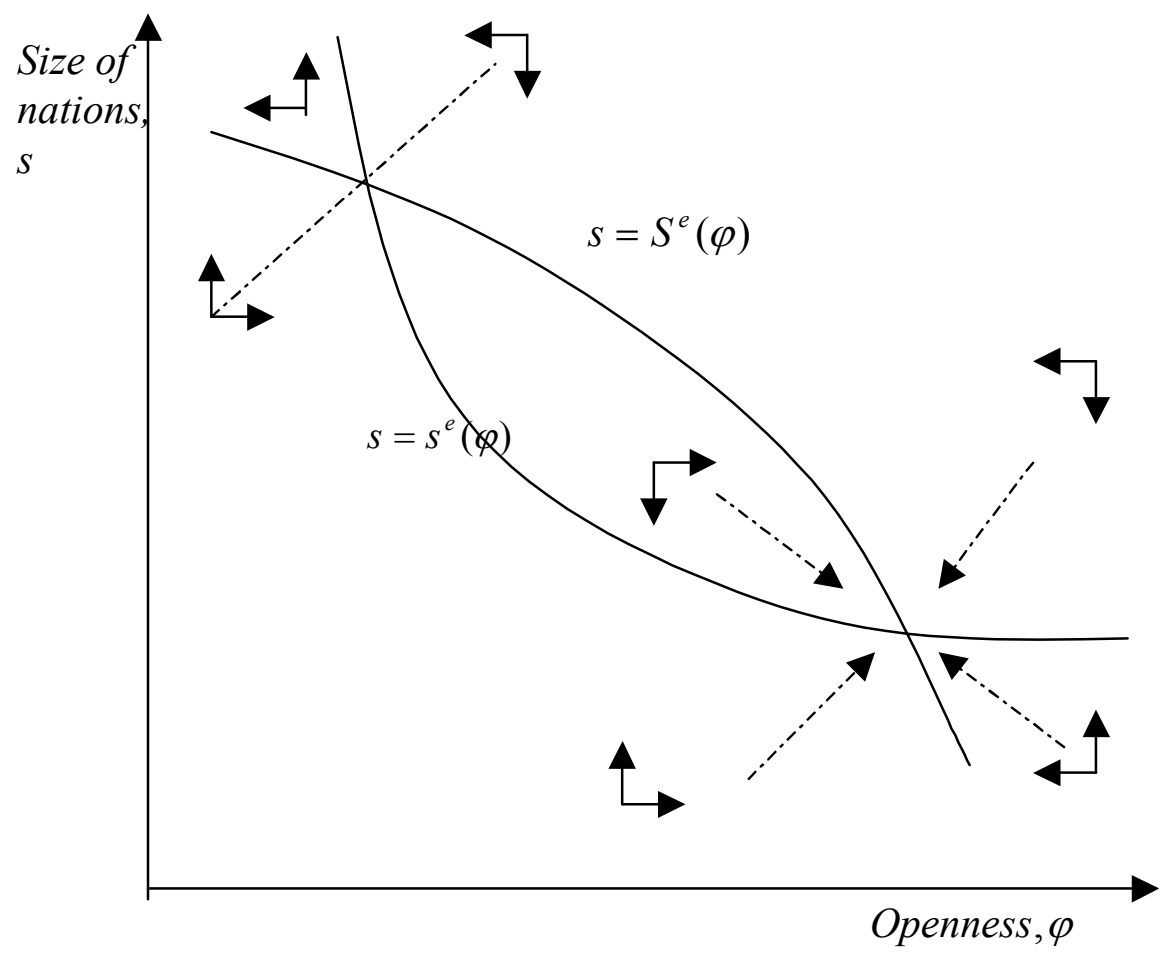

Figure 4. Geopolitical Dynamics

A new era of globalization started with the Industrial Revolution in the XIX century and, with the notable exceptions of two periods of globalization blacklash after 1870 and in the interwar period, globalization proceeded until today (see O'Rourke and Williamson, 1999). The number of periods increased quite rapidly in this period and the size of public sectors rapidly expanded. Our model is consistent with such a pattern since it implies that the process of reduction in the size of countries would be associated with at least an initial increase in the size of public spending. Only at a later stage there may be a decline (along the inverted $U$ curve which relates equilibrium public spending and the size of nations). One can see the initial increase in public spending in the raise of Communism in Eastern countries and in the raise of the welfare state in Western countries. A process of reduction in public spending associated with globalization is underway since the failure of Communism in most Eastern countries and the recent tendency toward the reduction of the public sector in Western countries. A possible prediction of our model is a further reduction of public spending in countries which are opening up to world markets. 


\section{Conclusion}

We have studied optimal and equilibrium political geography in a simple model where size of countries, public spending by their governments and globalization are endogenous. The optimal geography may not be a stable equilibrium and the Alesina-Spolaore bias toward too many nations tends to be confirmed. However, multiple equilibria can emerge with globalization backlash associated with large nations and high protectionism and equilibria with smaller countries and high openness which are also Pareto superior. A dynamic version of the model shows stable paths of decreasing size of nations, increasing globalization and (at least initially) increasing public spending. Such a process seems consistent with the hystorical experience, but it may converge toward a steady state with excessive globalization, too many countries and typically too much government spending.

The analysis can be extended microfounding the dynamic model with a more accurate description of the intertemporal links leading to break up of nations and change of policies and introducing geopolitical risk to study how this affects the equilibrium geography (on wars and democracy see Alesina and Spolaore, 1996 and Hess and Orphanides, 2001).

Finally it would be interesting to integrate the theory of political geography and the theory of economic geography. On the latter, recent important progress has been made by the pathbreaking contribution of Krugman (1991) who has been able to describe phenomena of industrial and urban location, regional specialization and international trade (see also Fujita, Krugman and Venables, 1999). Spatial heterogeneity, density population and scale economies are crucial there as here, but the interdependence between political and economic choices and political and economic geography still remains to be studied.

\section{Appendix I: A world of Leviathans}

Following AS I also solve for the equilibrium in the case central governments are dictatorial and extract rents from their countries. Let us assume for simplicity $\theta=0$ and $\lambda=1$. Imagine that to avoid coups, dictators have to provide the same utility as under anarchy to a fraction $\delta$ of the population. They cooperatively choose their policies to maximize total rents. Since the size of countries $s$ implies that there are $1 / s$ countries and each one creates rents $t s-g$ when per capita taxes are $t$ and public spending is $g$, the problem of the Leviathans becomes:

$$
\begin{aligned}
& \max _{t, s, g}(t s-g) \frac{1}{s} \\
\text { s.v. } \quad & g\left(1-a \frac{\delta s}{2}\right)+y-\frac{t^{2}}{2} \geq y
\end{aligned}
$$


Noticing that the contraint has to hold as an equality we have:

$$
\max _{t, s} t-\frac{t^{2}}{s(2-a \delta s)}
$$

which generates the Leviathans equilibrium:

$$
s^{L}=\frac{1}{a \delta} \quad t^{L}=\frac{1}{2 a \delta} \quad g^{L}=\frac{1}{4 a^{2} \delta^{2}}
$$

and the rents $1 / 4 a^{2} \delta^{2}$ per country. It follows that if the dictatorships are strong enough $(\delta<1 / 2)$ the size of countries and their per capita taxation are greater than in the optimal geography, but total public spending is still smaller than in the optimal geography as long as $\delta<1 / 2 \sqrt{2}$.

\section{Appendix II: Centralization bias}

Let us assume quadratic costs of heterogeneity in the distance from the public good, and for simplicity let us assume $\theta=0$ and $\lambda=1$. Utility for agent $i$ in district $j$ is now:

$$
U_{i j}=g_{j}\left[1-a l_{i j}^{2}\right]+y-\frac{t_{j}^{2}}{2}
$$

A social planner would choose size of districts and public good provision so as to maximize:

$$
W=\int_{0}^{1}\left[g_{j}\left[1-a l_{i j}^{2}\right]+y-\frac{t_{j}^{2}}{2}\right] d i \quad \text { s.v.: } s t_{j}=g_{j}
$$

or, after simple manipulation, it would solve the problem:

$$
\max _{g \geq 0, s \in[0,1]} W=g\left(1-\frac{a}{12} s^{2}\right)-\frac{1}{2}\left(\frac{g}{s}\right)^{2}+y
$$

where we used the fact that the expected cost of distance $l$ of a citizen from its public good is:

$$
a g \int_{0}^{\frac{s}{2}} \frac{l^{2}}{s / 2} d l=a g\left[\frac{2}{s}\left(\frac{l^{3}}{3}\right)\right]_{0}^{\frac{s}{2}}=a g \frac{s^{2}}{12}
$$

If we maximize welfare with respect to $s$ we obtain the first order condition:

$$
W_{s}=-a \frac{g s}{6}+\frac{g^{2}}{s^{3}}=0 \quad \Longleftrightarrow \quad s=\sqrt[4]{\frac{6 g}{a}}
$$

which gives us a first relationship between optimal size of districts and the optimal per capita provision of local public goods:

$$
t=\left(\frac{a}{6}\right) s \equiv \psi^{*}(s)
$$


Moreover, the Samuelson rule for optimal public good provision gives us a function of the size of a district which must satisfy the first order condition:

$$
W_{g}=1-\frac{a}{12} s^{2}-\frac{g}{s^{2}}=0 \quad \Longleftrightarrow \quad g=s^{2}\left(1-\frac{a}{12} s^{2}\right)
$$

or:

$$
t=s-\frac{a}{12} s \equiv \phi^{*}(s)
$$

which is an inverted $\mathrm{U}$ curve with a peak at $s=\frac{2}{\sqrt{a}}$. Solving the system of the two equations, we obtain the optimality conditions:

$$
\begin{aligned}
t^{*} & =\frac{4}{3 \sqrt{a}} \\
s^{*} & =\frac{2}{\sqrt{a}}
\end{aligned}
$$

In general, the optimal country would be composed by $N^{*}=\frac{\sqrt{a}}{2}$ districts, each one with a per capita public expenditure $t^{*}=\frac{4}{3 \sqrt{a}}$ and total provision of the public good $g^{*}=\frac{8}{3 a}$.

Let us now consider a decentralized equilibrium. In a district of size $s$, the favorite public expenditure by citizen $i$ is:

$$
\hat{g}_{i}=\arg \max g\left[1-a l_{i}^{2}\right]+y-\frac{(g / s)^{2}}{2}=\left[1-a l_{i}^{2}\right] s^{2}
$$

which is clearly a decreasing function of the distance from the center. Since single peakedness holds, the median voter theorem implies expenditure:

$$
\hat{g}_{m}=s^{2}\left(1-\frac{a}{16} s^{2}\right)
$$

which is above the optimal one for any district size because of the fact that the cost of distance for the median citizen is lower than the average cost of distance (they were equal with linear costs of heterogeneity). The important positive implication is that the political equilibrium per capita expenditure should be:

$$
t_{m}=s-\frac{a}{16} s^{3}
$$

which is a monotonic function increasing in size for small districts and decreasing for big districts. Now expected utility for a citizen at distance $l$ from the public good in a district of size $s$ is:

$$
\begin{aligned}
V(l) & =\hat{g}_{m}\left[1-a l^{2}\right]+y-\frac{\left(\frac{\hat{g}_{m}}{s}\right)^{2}}{2}= \\
& =\left[1-a\left(\frac{s}{4}\right)^{2}\right] s^{2}\left[1-a l^{2}\right]+y-\frac{1}{2}\left[1-a\left(\frac{s}{4}\right)^{2}\right]^{2} s^{2}
\end{aligned}
$$


Notice that now the utility of the median citizen is:

$$
V(s / 4)=\frac{1}{2}\left[1-a\left(\frac{s}{4}\right)^{2}\right]^{2} s^{2}+y
$$

which is maximized by the size $s=4 / \sqrt{3 a}>s^{*}$ which corresponds to a tax rate $t=8 / 3 \sqrt{3 a}>t^{*}$.

To limit the inefficiency of equilibria, one can imagine a form of geographical coordination. Let us consider a system in which the social planner can choose the geographical organization in districts but each district decides autonomously its public good provision. This would be the result of an efficient process of borders creation. In the latter stage, we know that utility in a district of size $s$ the political economy choice of public good provision generates the world welfare:

$$
\begin{aligned}
W(s) & =\hat{g}_{m}(s)\left(1-\frac{a}{12} s^{2}\right)-\frac{1}{2}\left(\frac{\hat{g}_{m}(s)}{s}\right)^{2}+y= \\
& =\frac{1}{2}\left(s^{2}-\frac{14 a}{96} s^{4}+\frac{a^{2}}{196} s^{6}\right)+y
\end{aligned}
$$

This is maximized by the size of districts:

$$
\tilde{s}=\frac{\sqrt{28-\sqrt{208}}}{\sqrt{3 a}}>s^{*}
$$

This second best has a straightforward intuition. Since districts tend to overprovide public goods, the central authority can improve the allocation of resources by fixing borders in such a way to have larger size of districts than in the first best so as to increase the scale economies. The best size is however smaller than the favourite size of the median citizen to limit the bias toward excessive provision.

\section{References}

Alesina, Alberto, Ignazio Angeloni and Federico Etro, 2001a, The Political Economy of International Unions, NBER wp N. 8645

Alesina, Alberto, Ignazio Angeloni and Federico Etro, 2001b, Institutional Rules for Federations, NBER wp N. 8646

Alesina, Alberto, Ignazio Angeloni and Federico Etro, 2003, International Unions, Harvard Institute of Economic Research, dp N. 2001

Alesina, Alberto, Reza Baqir and William Easterly, 1999, Public Goods and Etnich Division, Quarterly Journal of Economics,114 (4), 1243-84

Alesina, Alberto, Reza Baqir and Caroline Hoxby, 2002, Political Jurisdictions in Heterogeneous Communities, mimeo, Harvard University 
Alesina, Alberto and Enrico Spolaore, 1996, International Concflict, Defense Spending and the Size of Countries, NBER wp N. 5694

Alesina, Alberto and Enrico Spolaore, 1997, On the Number and Size of Nations, Quarterly Journal of Economics, 112:4, 1027-56

Alesina, Alberto and Enrico Spolaore, 2003, The Size of Nations, MIT Press, Cambridge

Alesina, Alberto, Enrico Spolaore and Romain Wacziarg, 2000, Economic Integration and Political Disintegration, American Economic Review, 90 (5), 1276-97

Alesina, Alberto and Romain Wacziarg, 1998, Openness, Country Size and the Government, Journal of Public Economics, 69, 3, 305-21

Atkinson, Anthony and Joseph Stiglitz, 1980, Lectures in Public Economics, McGraw Hill, London

Besley, Timothy and Stephen Coate, 2003, Centralized versus Decentralized Provision of Public Goods: A Political Economy Analysis, forthcoming, Journal of Public Economics

Bolton, Patrick and Gerard Roland, 1997, The Breakup of Nations: A Political Economy Analysis, Quarterly Journal of Economics, 112 (4), 1057-90

Boadway, Robin and Frank Flatters, 1982, Efficiency and Equalization Payments in a Federal System of Government: a Synthesis and Extension of Recent Results, Canadian Journal of Economics, XV, 4, 613-33

Bordignon, Massimo and Sandro Brusco, 2001, Optimal Secession Rules, European Economic Review, 45, 1811-34

Bordignon, Massimo, Paolo Manasse and Guido Tabellini, 2001, Optimal Regional Redistribution, The American Economic Review, 91 (3), 709-23

Brueckner, Jan K., 1979, Spatial Majority Voting Equilibria and the Provision of Public Goods, Journal of Urban Economics, 6, 338-51

Brueckner, Jan K., 2000, A Tiebout/tax competition Model, Journal of Public Economics, 77, 285-306

Buchanan, James, 1965, An Economic Theory of Clubs, Economica

Buchanan, James and R. L. Faith, 1987, Secession and the Limits of Taxation: Toward a Theory of Internal Exit, The American Economic Review, 77, 1023-31

Ellickson, Brian, 1971, Jurisdictional Fragmentation and Residential Choice, The American Economic Review, 61 (2), 334-39

Epple, Dennis and Thomas Romer, 1991, Mobility and Redistribution, Journal of Political Economy, 99 (4), 828-58

Etro, Federico, 2002, International Policy Coordination with Economic Unions, Rivista Internazionale di Scienze Sociali, 110 (2), 187-211

Etro, Federico and Piero Giarda, 2002, Redistribution, Decentralization and Constitutional Rules, QIEF 49, UCSC, Milan

Fujita, Masahisa, 1989, Urban Economic Theory. Land Use and City Size, Cambridge, Cambridge University Press

Fujita, Masahisa, Paul Krugman and Anthony Venables, 1999, The Spatial Economy, Cambridge, MIT Press 
Gordon, Roger H., 1983, An Optimal Taxation Approach to Fiscal Federalism, Quarterly Journal of Economics, November, 567-86

Gradstein, Mark, 2002a, The Political Economy of Sustainable Federations, mimeo, Ben Gurion University, Israel

Gradstein, Mark, 2002b, Political Bargaining in a Federation: Buchanan meets Coase, mimeo, Ben Gurion University, Israel

Grossman, Gene and Elhanan Helpman, 1991, Innovation in the Global Economy, MIT Press

Hess, Gregory and Athanasios Orphanides, 2001, War and Democracy, Journal of Political Economy, 109, 4, 776-810

Haimanko, Ori, Michel Le Breton and Shlomo Weber, 2001, Transfers in a polarized Country: Bridging the Gap between Efficiency and Stability, mimeo, Catholic university of Louvain

Hotelling, Harold, 1929, Stability and Competition, The Economic Journal, 39(1), 41- 57

Kanbur, Ravi and Michael Keen, 1993, Jeux sans Frontiers: Tax Competition and Tax Coordination when Countries differ in Size, The American Economic Review, 83, 877-92

Krugman, Paul, 1991, Increasing Returns and Economic Geography, Journal of Political Economy, 99, 483-99

Oates, Wallace, 1972, Fiscal Federalism, New York, Harcourt Brace Jovanovich

Oates, Wallace, 1999, An Essay on Fiscal Federalism, Journal of Economic Literature, 37, 3, 1120-49

O'Rourke, Kevin and Jeff Williamson, 1999, Globalization and History: The Evolution of a 19th Century Atlantic Economy, Cambridge, MIT Press

Rivera-Batiz, Luis and Paul Romer, 1990, Economic Integration and Endogenous Growth, Quarterly Journal of Economics, 106, 2, 531-55

Rodrik, Dani, 1998, Why do more Open Countries have Larger Governments?, Journal of Political Economy, 106, 5

Samuelson, Paul, 1955, Diagrammatic Exposition of a Theory of Public Expenditure, Review of Economic and Statistics, 37 (4), 350-56

Sørensen, Peter Birch, 2003, International Tax Coordination: Regionalism versus Globalism, forthcoming, Journal of Public Economics

Spolaore, Enrico and Romain Wacziarg, 2002, Borders and Growth, mimeo, Brown University

Strumpf, Koleman S. and Felix Oberholzer-Gee, 2002, Endogenous Policy Decentralization: Testing the Central Tenet of Economic Federalism, Journal of Political Economy, 110 (1), 1-36

Tiebout, Charles M., 1956, A Pure Theory of local Expenditures, Journal of Political Economy, 416-24

Wildasin, D.E., 1988, Nash Equilibria in Models of Fiscal Competition, Journal of Public Economics, 35, 241-9 


\title{
CESifo Working Paper Series
}

\author{
(for full list see www.cesifo.de)
}

920 Klaus Wälde, Endogenous Business Cycles and Growth, April 2003

921 Ramon Castillo and Stergios Skaperdas, All in the Family or Public? Law and Appropriative Costs as Determinants of Ownership Structure, April 2003

922 Peter Fredriksson and Bertil Holmlund, Improving Incentives in Unemployment Insurance: A Review of Recent Research, April 2003

923 Bernard M.S. van Praag and Adam S. Booij, Risk Aversion and the Subjective Time Discount Rate: A Joint Approach, April 2003

924 Yin-Wong Cheung, Kon S. Lai, and Michael Bergman, Dissecting the PPP Puzzle: The Unconventional Roles of Nominal Exchange Rate and Price Adjustment, April 2003

925 Ugo Trivellato and Anna Giraldo, Assessing the 'Choosiness' of Job Seekers. An Exploratory Approach and Evidence for Italy, April 2003

926 Rudi Dornbusch and Stanley Fischer, International Financial Crises, April 2003

927 David-Jan Jansen and Jakob de Haan, Statements of ECB Officials and their Effect on the Level and Volatility of the Euro-Dollar Exchange Rate, April 2003

928 Mario Jametti and Thomas von Ungern-Sternberg, Assessing the Efficiency of an Insurance Provider - A Measurement Error Approach, April 2003

929 Paolo M. Panteghini and Guttorm Schjelderup, Competing for Foreign Direct Investments: A Real Options Approach, April 2003

930 Ansgar Belke, Rainer Fehn, and Neil Foster, Does Venture Capital Investment Spur Employment Growth?, April 2003

931 Assar Lindbeck, Sten Nyberg, and Jörgen W. Weibull, Social Norms and Welfare State Dynamics, April 2003

932 Myrna Wooders and Ben Zissimos, Hotelling Tax Competition, April 2003

933 Torben M. Andersen, From Excess to Shortage - Recent Developments in the Danish Labour Market, April 2003

934 Paolo M. Panteghini and Carlo Scarpa, Irreversible Investments and Regulatory Risk, April 2003 
935 Henrik Jacobsen Kleven and Claus Thustrup Kreiner, The Marginal Cost of Public Funds in OECD Countries. Hours of Work Versus Labor Force Participation, April 2003

936 Klaus Adam, George W. Evans, and Seppo Honkapohja, Are Stationary Hyperinflation Paths Learnable?, April 2003

937 Ulrich Hange, Education Policy and Mobility: Some Basic Results, May 2003

938 Sören Blomquist and Vidar Christiansen, Is there a Case for Public Provision of Private Goods if Preferences are Heterogeneous? An Example with Day Care, May 2003

939 Hendrik Jürges, Kerstin Schneider, and Felix Büchel, The Effect of Central Exit Examinations on Student Achievement: Quasi-experimental Evidence from TIMSS Germany, May 2003

940 Samuel Bentolila and Juan F. Jimeno, Spanish Unemployment: The End of the Wild Ride?, May 2003

941 Thorsten Bayindir-Upmann and Anke Gerber, The Kalai-Smorodinsky Solution in Labor-Market Negotiations, May 2003

942 Ronnie Schöb, Workfare and Trade Unions: Labor Market Repercussions of Welfare Reform, May 2003

943 Marko Köthenbürger, Tax Competition in a Fiscal Union with Decentralized Leadership, May 2003

944 Albert Banal-Estañol, Inés Macho-Stadler, and Jo Seldeslachts, Mergers, Investment Decisions and Internal Organisation, May 2003

945 Kaniska Dam and David Pérez-Castrillo, The Principal-Agent Matching Market, May 2003

946 Ronnie Schöb, The Double Dividend Hypothesis of Environmental Taxes: A Survey, May 2003

947 Erkki Koskela and Mikko Puhakka, Stabilizing Competitive Cycles with Distortionary Taxation, May 2003

948 Steffen Huck and Kai A. Konrad, Strategic Trade Policy and Merger Profitability, May 2003

949 Frederick van der Ploeg, Beyond the Dogma of the Fixed Book Price Agreement, May 2003

950 Thomas Eichner and Rüdiger Pethig, A Microfoundation of Predator-Prey Dynamics, May 2003

951 Burkhard Heer and Bernd Süssmuth, Cold Progression and its Effects on Income Distribution, May 2003 
952 Yu-Fu Chen and Michael Funke, Labour Demand in Germany: An Assessment of NonWage Labour Costs, May 2003

953 Hans Gersbach and Hans Haller, Competitive Markets, Collective Decisions and Group Formation, May 2003

954 Armin Falk, Urs Fischbacher, and Simon Gächter, Living in Two Neighborhoods Social Interactions in the LAB, May 2003

955 Margarita Katsimi, Training, Job Security and Incentive Wages, May 2003

956 Clemens Fuest, Bernd Huber, and Jack Mintz, Capital Mobility and Tax Competition: A Survey, May 2003

957 Edward Castronova, The Price of 'Man' and 'Woman': A Hedonic Pricing Model of Avatar Attributes in a Synthetic World, June 2003

958 Laura Bottazzi and Marco Da Rin, Financing Entrepreneurial Firms in Europe: Facts, Issues, and Research Agenda, June 2003

959 Bruno S. Frey and Matthias Benz, Being Independent is a Great Thing: Subjective Evaluations of Self-Employment and Hierarchy, June 2003

960 Aaron Tornell and Frank Westermann, Credit Market Imperfections in Middle Income Countries, June 2003

961 Hans-Werner Sinn and Wolfgang Ochel, Social Union, Convergence and Migration, June 2003

962 Michael P. Devereux, Measuring Taxes on Income from Capital, June 2003

963 Jakob de Haan, Jan-Egbert Sturm and Bjørn Volkerink, How to Measure the Tax Burden on Labour at the Macro-Level?, June 2003

964 Harry Grubert, The Tax Burden on Cross-Border Investment: Company Strategies and Country Responses, June 2003

965 Kirk A. Collins and James B. Davies, Measuring Effective Tax Rates on Human Capital: Methodology and an Application to Canada, June 2003

966 W. Steven Clark, Using Micro-Data to Assess Average Tax Rates, June 2003

967 Christopher Heady, The 'Taxing Wages' Approach to Measuring the Tax Burden on Labour, June 2003

968 Michael P. Devereux and Alexander Klemm, Measuring Taxes on Income from Capital: Evidence from the UK, June 2003

969 Bernhard Eckwert and Itzhak Zilcha, The Effect of Better Information on Income Inequality, June 2003 
970 Hartmut Egger and Josef Falkinger, The Role of Public Infrastructure for Firm Location and International Outsourcing, June 2003

971 Dag Morten Dalen and Trond E. Olsen, Regulatory Competition and Multi-national Banking, June 2003

972 Matthias Wrede, Tax Deductibility of Commuting Expenses and Residential Land Use with more than one Center, June 2003

973 Alessandro Cigno and Annalisa Luporini, Scholarships or Student Loans? Subsidizing Higher Education in the Presence of Moral Hazard, June 2003

974 Chang Woon Nam, Andrea Gebauer and Rüdiger Parsche, Is the Completion of EU Single Market Hindered by VAT Evasion?, June 2003

975 Michael Braulke and Giacomo Corneo, Capital Taxation May Survive in Open Economies, July 2003

976 Assar Lindbeck, An Essay on Welfare State Dynamics, July 2003

977 Henrik Jordahl and Luca Micheletto, Optimal Utilitarian Taxation and Horizontal Equity, July 2003

978 Martin D. D. Evans and Richard K. Lyons, Are Different-Currency Assets Imperfect Substitutes?, July 2003

979 Thorsten Bayindir-Upmann and Frank Stähler, Market Entry Regulation and International Competition, July 2003

980 Vivek Ghosal, Firm and Establishment Volatility: The Role of Sunk Costs, Profit Uncertainty and Technological Change, July 2003

981 Christopher A. Pissarides, Unemployment in Britain: A European Success Story, July 2003

982 Wolfgang Buchholz, Richard Cornes, and Wolfgang Peters, On the Frequency of Interior Cournot-Nash Equilibria in a Public Good Economy, July 2003

983 Syed M. Ahsan and Panagiotis Tsigaris, Choice of Tax Base Revisited: Cash Flow vs. Prepayment Approaches to Consumption Taxation, July 2003

984 Campbell Leith and Jim Malley, A Sectoral Analysis of Price-Setting Behavior in US Manufacturing Industries, July 2003

985 Hyun Park and Apostolis Philippopoulos, Choosing Club Membership under Tax Competition and Free Riding, July 2003

986 Federico Etro, Globalization and Political Geography, July 2003 